\title{
AMINO ACID ELEMENTS OF NORMAL HUMAN AQUEOUS FLUID PROTEIN*
}

\author{
BY \\ WOLFRAM KEUP AND RAINER STEIGER \\ From the University Eye Clinic, Zürich (Director: Prof. Dr. Marc Amsler)
}

EARLY analyses of the proteins of the normal aqueous humour by Franceschetti and Wieland (1928), and later by Kronfeld (1941) and Kronfeld and others (1941), have shown a content of 10 to $20 \mathrm{mg}$. per cent. Any functional significance this protein may have is unknown. However, the human lens contains 30-40 psr cent. protein, the fractions of which have been determined by several authors (Cagianut and others, 1953 ; Stemmermann, 1952). The lens protein is built up by the capsular epithelium, which, because of its avascularity, must draw the constituent elements of protein synthesis from the aqueous alone. Neither the free nor the protein-bound amino acids of the aqueous humour have hitherto been determined by reliable methods. The reasons for this are, first, that the aqueous contains extremely small amounts of protein and free amino acids, and, second, that there is a very large concentration of inorganic ions in proportion to that of the amino acids.

In this communication, the composition of the amino acids present in normal human aqueous fluid protein is reported.

\section{Method}

Anterior chamber punctures were performed on normal human eyes, most of which were amblyopic, and the aqueous humour was collected over a period of time and stored in the deep-freeze. The protein of this fluid was precipitated with absolute alcohol (total concentration 80 per cent.). The precipitate was centrifuged out and dried. The total yield was $10 \mathrm{mg}$. dried material. This was totally hydrolysed with $5 \mathrm{~N}$ hydrochloric acid by reflux condensation for $24 \mathrm{hrs}$.

In the hydrolysate, fifteen amino acids were quantitatively determined by the chromatography method of Pernis and Wunderly (1953) modified by Gerok (1955). The procedure is as follows:

A quantity of hydrolysate corresponding to a total of 150 gamma of amino acids is placed on the starting point of a two-dimensional chromatogram, and developed in the first run with Partridge mixture (Butanol-glacial acetic acid-water). It is then dried, developed on the second run with $\mathrm{m}$-Cresol-phenol-borate buffer, and dried once again. This two-dimensional developed chromatogram is sprayed with Moore-Stein reagent; when it is warmed, violet spots appear indicating the reaction of the amino acids with ninhydrin (Figure). The spots are cut out, fragmented, extracted, and quantitatively coloured with further Moore-Stein reagent in a simmering water-bath. The extraction solution is quantitatively measured colorimetrically in a Beckman spectrophotometer

* Received for publication January 1, 1955. 
at $570 \mathrm{~m} \mu$, the proline similarly at $440 \mathrm{~m} \mu$. The computation, after subtraction of the blanks of reagent and amino-acid-free paper, yields absolute values for the amino acids. The method is calibrated with known amounts of all the examined amino acids. The values are computed as percentages of the whole amino acids.

Since the experimental error of the procedure is greater than originally supposed by previous workers, the determinations were carried out eight times; amino acids with high and low Rf-values were measured four times, while those with middle Rf-values were measured eight times (see Table, opposite).

\section{Findings}

As would be expected, the qualitative analysis of the protein hydrolysates indicated the presence of all the determined amino acids (Figure).

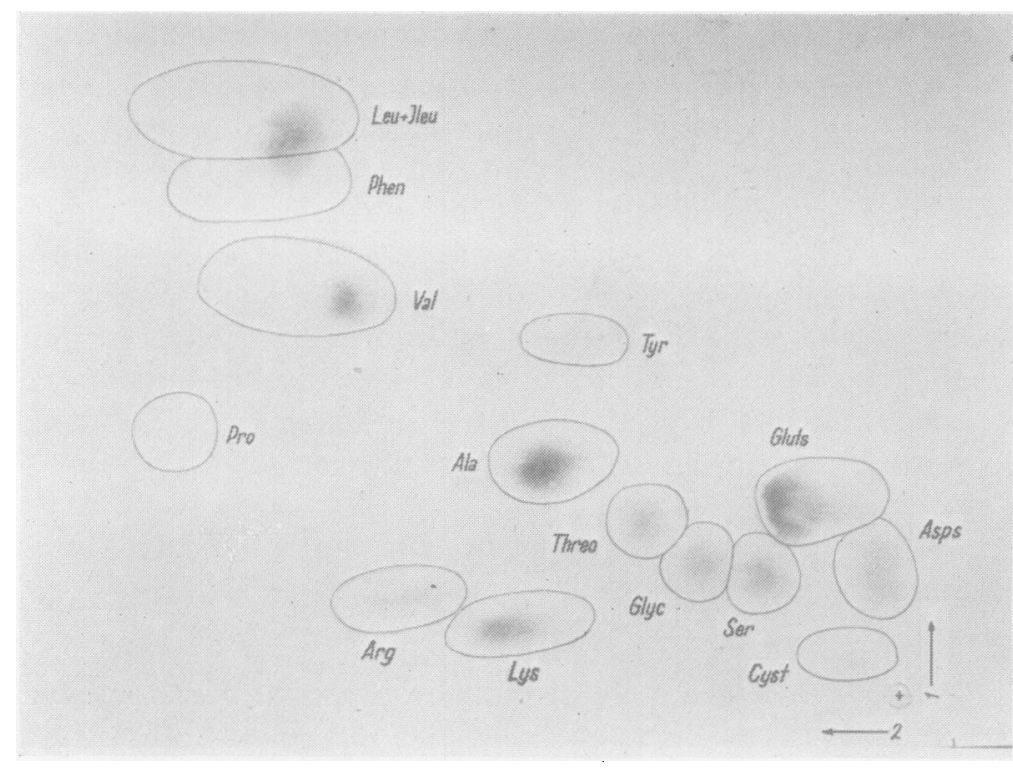

FIGURE.-Two-dimensional chromatogram, showing constituent amino acids of aqueous proteins.

The quantitative relationships of the amino acids are shown in the Table (Col. 2). They may be compared with the serum protein amino acid analysis of Pernis (1953), in which a similar method was used.

The values shown in Col. 1, representing the total protein in normal aqueous, were computed as follows:

The quantities of electrophoretic fractions in normal aqueous humour were listed by Esser and others (1954):

Pre-albumin 0.6 per cent.

Albumin 64.9 per cent.

$\alpha_{1}$-globulin 4.8 per cent.

$\alpha_{2}$-globulin $7 \cdot 1$ per cent.

$\beta$-globulin 18.5 per cent.

$\gamma$-globulin $4 \cdot 1$ per cent. 
These values are multiplied by the individual amino-acid percentage of whole amino acids, as determined by Pernis (1953), for each fraction of serum proteins. The values so obtained correspond to whole serum protein with the electrophoretic composition of normal aqueous, and are comparable with it.

TABLE

AMINO-ACID COMPOSITION OF TOTAL AQUEOUS FLUID PROTEIN COMPARED WITH CALCULATED SERUM-PROTEIN AND LENS-PROTEIN

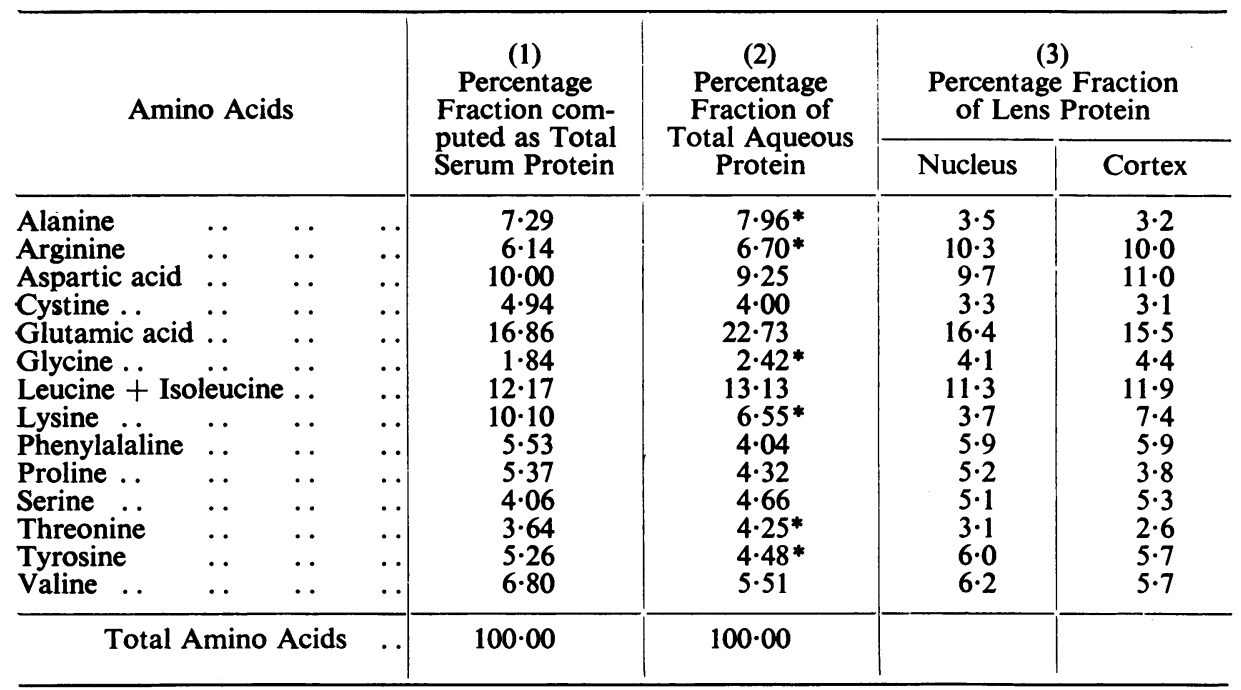

*Indicates average derived from eight determinations, other results are obtained from four determinations.

If it be assumed that the serum proteins reach the aqueous exclusively by diffusion, the computed anticipated composition should correspond to the experimentally determined composition within the limits of the experimental error of the method, but certain disparities are seen between Cols 1 and 2 (Table), particularly in the values for glutamic acid and lysine.

If it be assumed that the lens protein is derived from the aqueous protein by a process of rebuilding, no large disparity in its " components" should be expected, but a comparison between Cols 2 and 3 (Table) also shows certain considerable disparities both in glutamic acid and lysine, and in arginine and alanine. It should be mentioned that a conversion to individual electrophoretic fractions was not possible in this case.

\section{Discussion}

Stemmermann (1952) obtained electrophoretic diagrams, by a paperelectrophoretic method, of the soluble lens proteins as recognized from the soluble tissue-proteins of other organs (Demling and others, 1954). The relationship with the serum proteins estimated by Stemmermann has come under question, since Keup (1955), using the Tiselius electrophoresis, has shown that, for the soluble tissue proteins of the brain, the mobilities of the tissue proteins are much higher than those of the serum proteins. The 
mobilities cannot be exactly determined by paper electrophoresis; as previously expected on theoretical grounds, one is dealing with tissue proteins, the properties of which almost certainly differ from those of the serum proteins.

The origin of lens protein is still as uncertain as that of other tissue proteins. Whether the serum protein is used in the synthesis of these proteins, as Whipple (1948) assumed, or the free amino acids of the serum, as Dent (1950) conjectures, has not been ascertained. Because of the absence of a vascular supply, however, the only sources for the synthesis of lens proteins, considered as organ-proteins, are the proteins or free amino acids present in the aqueous.

Cagianut and others (1953) have recently reported on the amino acid composition of the protein of a normal human lens. Their values may be compared with our findings set out in the Table. The interpretation of our findings and of the differences found in the amino acid composition remains unsolved. The determination of the quantitative relationships of the free amino acids in normal human aqueous will bring the problem a step further towards solution.

\section{Summary}

The amino acid elements of the proteins of normal human aqueous have been qualitatively and quantitatively determined, and the values compared with those of the serum and lens protein.

We wish to thank Dr. H. R. Bohringer, Chief Resident Surgeon of this Clinic, for his kind clinical advice.

\section{REFËRENCES}

Cagianut, B., Pernis, B., and Wunderly, C. (1953). Experientia; 9, 218.

Demling, L., KINZLMEIER, H., and HeNniNG, N. (1954). Z. ges. exp. Med., 122, 416.

DENT, C. E. (1950) Schweiz. med. Wschr., 80, 752.

Esser, H. F., Heinzler, F., and PAU, H. (1954). v. Graefes Arch. Ophthal., 155, 11.

FrANCESCHETTI, A., and WIELAND, H. (1928). Arch. Augenheilk., 99, 45.

GEROK, W. (1955). Hoppe-Seyl. Z., 299, 112.

KEUP, W. (1955). Confinia neurol., 15, 73.

KRONFELD, P. C. (1941). Amer. J. Ophthal., 24, 1121.

, LIN, C. K., and Luo, T. H. (1941). Ibid., 24, 264.

PERnis, B. (1953). Plasma, 1, 365.

PERN, and WUNDERLY, C. (1953). Biochim. biophys. Acta, 11, 209.

StemmermanN, W. (1952). Klin. Wschr., 30, 1102.

WhIPple, G. H. (1948). “ Hemoglobin, Plasma Protein, and Cell Protein”, American Lecture Series No. 12. Thomas, Springfield, Ill.

WunderLy, C., and CAGIANUT, B. (1954). British Journal of Ophthalmology, $38,357$. 